$$
\begin{aligned}
& \text { 近地地震のマグニチュード } \\
& \text { 京都大学理学部阿武山地震観測所 渡 辺晃 } \\
& \text { (昭和 } 46 \text { 年 } 6 \text { 月 } 23 \text { 日受理) }
\end{aligned}
$$

\title{
Determination of Earthquake Magnitude at Regional Distance in and near Japan
}

\author{
Hikaru WATANABE \\ Abuyama Seismological Observatory, \\ Faculty of Science, Kyoto University
}

(Received June 23, 1971)

Several formulas to determine the magnitudes of earthquakes with shallow foci from amplitude and focal distance in the regional range up to about $1,000 \mathrm{~km}$, were newly derived by using the data observed at the Abuyama Seismological Observatory and its array stations, and compared in the cases from displacement and velocity seismograms.

The patterns of maximum amplitudes versus focal distances show that the manner of decay of the displacement amplitude is practically similar to that of velocity amplitude in the distance range up to $200 \mathrm{~km}$, but markedly different in the range over $200 \mathrm{~km}$, because the phase of the seismic wave corresponding to the maximum amplitude varies from the body wave to the surface wave at the focal distance around $200 \mathrm{~km}$ and the long period surface wave is sharply cut off with the steep slope of the frequency response curve of the velocity seismograph.

The amplitude-distance curves at the close distance range up to about $40 \mathrm{~km}$, however, are folded in the case of displacement amplitude. This phenomenon may arise from the effect of exitation of refracted or reflected, or both phases having longer periods, resulting in an increase of about 0.3 in the magnitude value. Taking no account of these slight folds, the decay of the maximum amplitude is supposed to be nearly uniform throughout the distance range concerned. Thus, the decay factor, including the geometrical spreading, is estimated as $r^{-1.73}$, which is just the same as in the Tsuboi's (1954) formula.

The periods corresponding to the maximum amplitude were found to increase according to the earthquake sizes alone, when the same type of phase was traced. On the basis of this finding; an attempt was made to infer the relation between the source factor of displacement spectral density and the magnitude.

\section{$\S 1$ はじめに}

地震波の振幅からマグニチュード $M$ を決める場合，その波動が実体波であるか表面波であ るかによつて計算方法が異なつてくる. 従つて地震計の型を決め, 読みとるべき周期を指定し

昭和 46 年 5 月 19 日地震学会で発表. 
ておけば波動の種類が自然に決まるので， $M$ の決定精度が向上する．例えば，短周期実体波 を使つて計算した $m_{B}$ ，長周期表面波による $M_{s}$ などはこのような考方方を基にしたものであ る. しかしこの際，地震の規模および震源距離の違いにょつて起る波動スペクトルの变化に留 意しなければならない。

これに対して，従来，一般的に行なわれているのは，変位型地震計の記録で波の種類を選ば ず，最大振幅を用いる方法である。この方法では，あらかじめ波動スペクトルの最大值が地震 計の cut off 周波数から大きくはずれていないことを確めて沶かなければならない。なぜな らば，使用する地震計によつて，対象とする地震の規模や震源距離の範囲が制限され，この範 囲を越えるものについては誤差が大きくなるからである。この範囲を拡げるには，感度和よび 周波数带域の異なつたいくつかの地震計を組み合わせて使用すればよい．阿武山地震観測所で は，Fig. 1 に示す地震計を組み合わせて，広い周波数帯域と dynamic range を得ることがで きる. 以下，この方法で震源距離 $1,000 \mathrm{~km}$ 以内の浅発地震を対象とした $M$ の定義式をつく り，従来のものとの比較を行なつた。ささらに，周波数特性の異なつた地震記象を比べることに よつて，地震波のスペクトルとの $M$ 関係について一つの推論を行なつた.

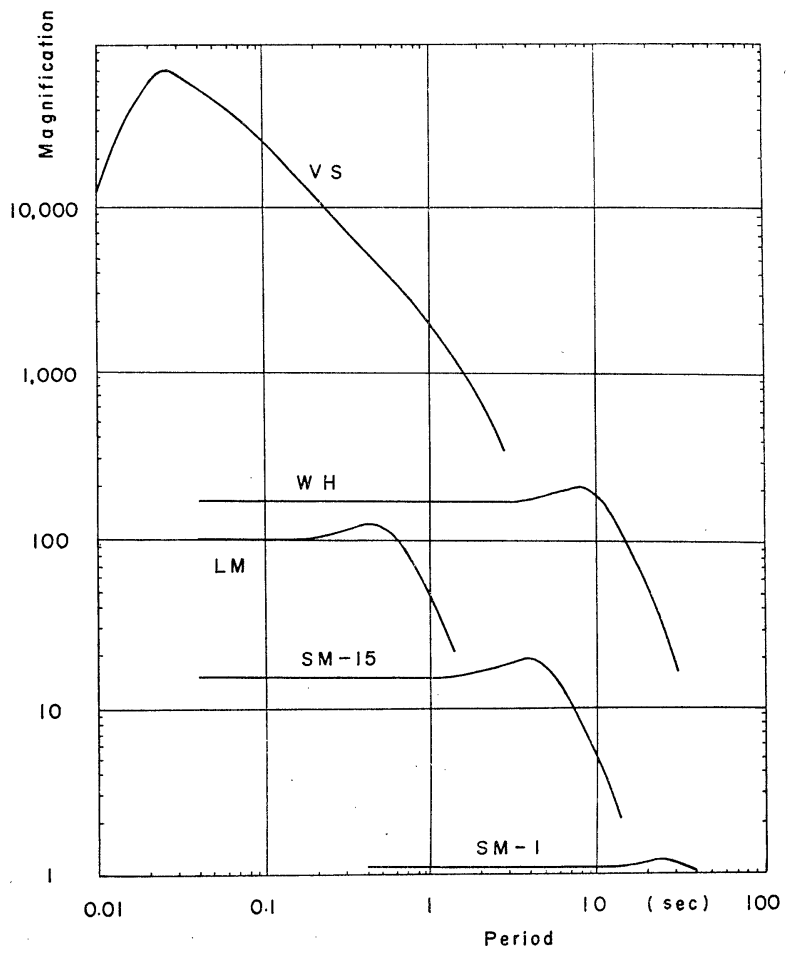

Fig. 1. Frequency response curve being used at the Abuyama Seismological Observatory and its array stations. 


\section{$\S 2$ 変位振幅から求めたマグニチュード}

記録上の最大振幅に着目して地震の Instrumental Magnitude Scale $(M)$ を決めるのは, もともと RICHTER (1935) の定義によるものである. 最大振幅を与える地震波形は，地震の深 さ，発震機構，地震計の周期特性などにょりさまざまに変化するので，この方法を用いると観 測点によつては $M$ の值に大きな䛊差を生ずることがある. しかし実際の手続が簡便に行なえ るので，この方法は RICHTER が定義したものから形を变えながら広く用いられている．Mの 誤差を小さくするには，まず，地震の深さを限定し震源をとり囲んだ多数の観測値から適当な 方法で平均值を求めればよい，また地震計の変位に対して平坦な帯域を広くする必要がある.

気象庁で決定されるマグニチュード $\left(M_{J}\right)$ は，このような点を考慮し計算されているので， 現在我国での最も信頼度の高い $M$ の值を与えている.

ところで $M_{J}$ の計算の基礎になつているのは坪井（1954）の式であり，次式で表わされる.

$$
M=\log A+\alpha \log \gamma+\beta, \quad \alpha=1.73, \beta=-0.83
$$

$A$ は変位計の最大振幅を地動に換算し $\mu$ で表わしたものであり， $r$ は震源距離を $\mathrm{km}$ で示し たものである．この式を用い阿武山の資料から決めたマグニチュード $(M o)$ と $M_{J}$ を比較し たのが Fig. 2 および Fig. 3 である. $A$ は水平動 2 成分の合成で求めた最大值 (片振幅)を $\mu$

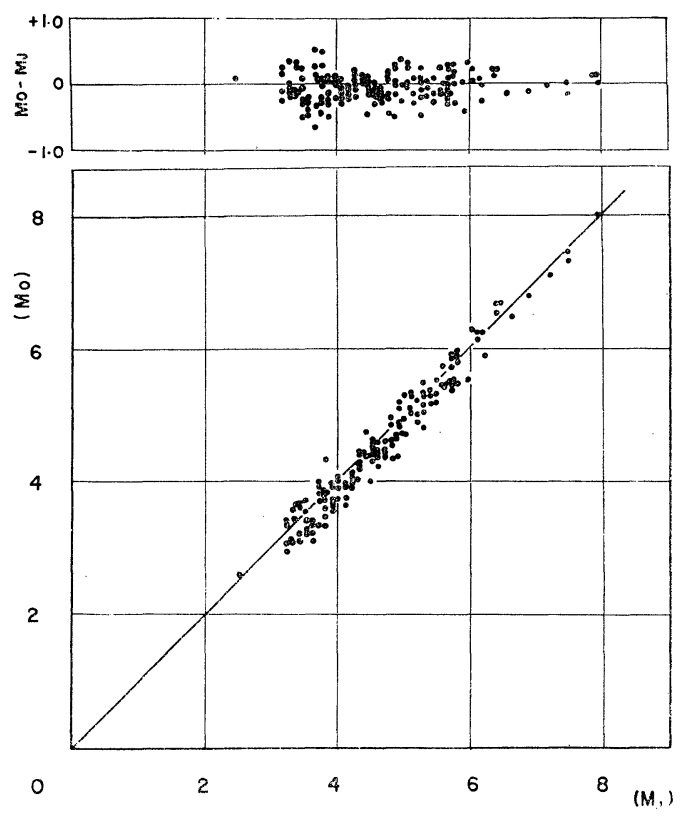

Fig. 2. The relations between the magnitudes determined by J. M. A. $\left(M_{J}\right)$ and by the present writer using the data of displacement seismographs (Mo). There is a good correlation between $M_{J}$ and $M o$ within the wide range of magnitude. 


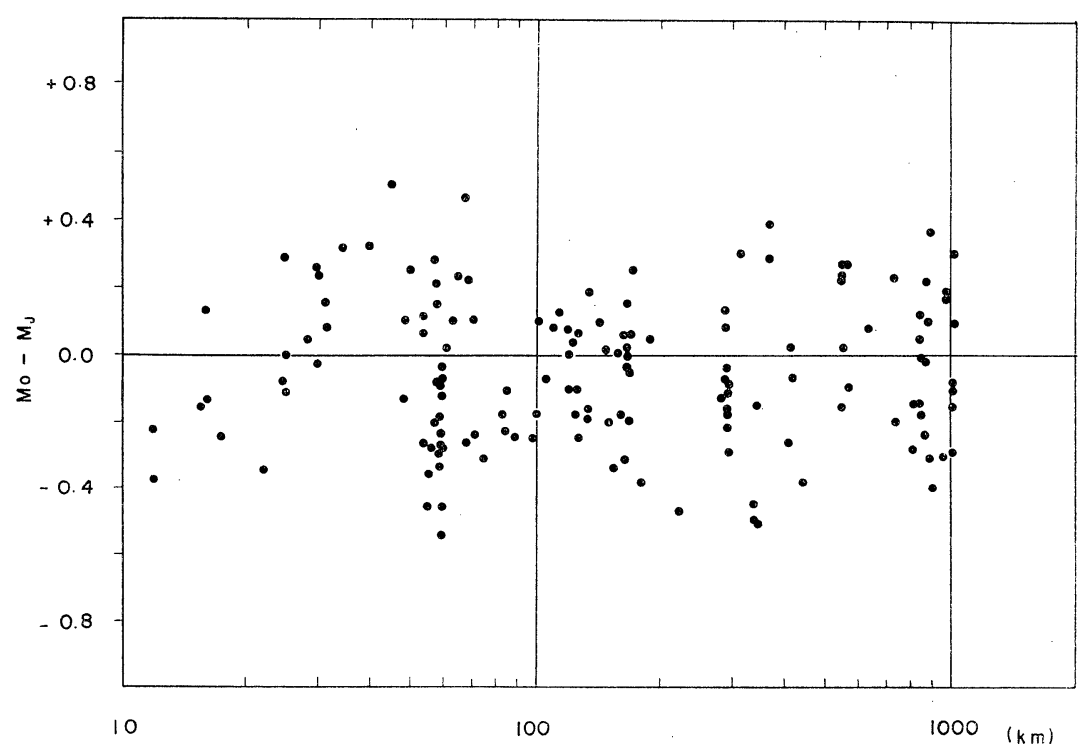

Fig. 3. $M o-M_{J}$ versus focal distance. No systematic deviation with respect to focal distance is seen except in the close distance range up to about $40 \mathrm{~km}$.

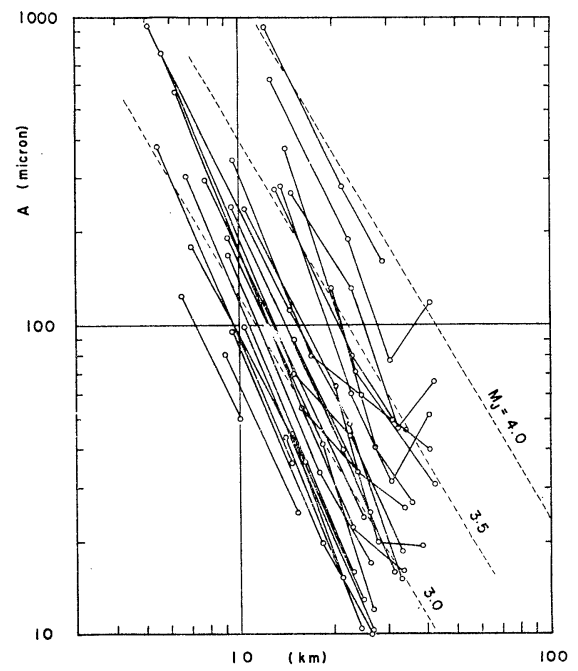

Fig. 4. The pattern of maximum displacement amplitude $(A)$ versus focal distance $(r)$ obtained from the array observations in the vicinity of Matsushiro. The dashed lines indicate the magnitude scale of J. M. A..

単位で表わしたので，気象庁と同じ手続をとつている．Fig. 2 は $M$ の広い範囲で系統的な偏 りが殆んどないことを示している。䛊差の平均值および分散は $\overline{M o-M_{J}}=-0.06, \sigma^{2}=\Sigma(M o-$ $\left.M_{J}\right)^{2} / n=0.12$ である.すなわち, Fig.1 に示すような变位計群を使えば, 1 観測点の資料から 
比較的精度よく $M$ が求まることを示している.さらに阿武山に当てはまる (1)式の係数は坪 井の式のそれに近いものであり， station correction などの補正を行なう必要のないことが分 る. 次に, Fig. 3 は同じ資料を震源距離 $r$ にいて示したものである. 全体としてのばらつ きには，rに対しても系統的な偏りはみられない。 しかしこまかく調べると， $r<40 \mathrm{~km} の$ 範囲で $M o-M_{J}$ が負から正へ移り変つていることが分る. 同じ傾向は $r=70 \sim 120 \mathrm{~km}$ に拉 いてもみられる，この現象を説明するためには，さらに詳しい資料が必要である．Fig. 4 は松 代地震の群列観測で得られた $A \sim r$ 曲線である. 図の鎖線は（1）式の関係を表わしている. $M_{J}$ の決まつた地震について（1）式と比較すれば，いずれも傾斜が大きく $M_{J}$ に対応する鎖 線, 屈折より下にくる. しかし, これは $r=40 \mathrm{~km}$ 前後で急に折れ曲り, 鎖線を跳び越すもの もでてくる.この jump の大きさは地震の深さ拈よび距離によつて变化する．このような事実 は，すでにいくつか報告されているが〔例えば，梅田（1968）,EVERNDEN (1967)]，地震波の 反射，屈折などによる変成波の生成過程に関係する現象であると考えられる，このことは，S 波の初動が単調に減少しているにも拘らず，最大振幅を与える波形が jump を起す観測点附 近で急に変化している事実からも説明されるであろう。しかしさらに立入つた議論は他の論文 にゆずりたい。

前に述べた $r=70 \sim 120 \mathrm{~km}$ での jump もこれと同様に考えることができるので，A〜r曲 線はこのような凹凹をくり返しながら全体として（1）式で表現されるのであろら。ちなみに Fig. 4 から最小自乗法で係数を決めると次式が得られる.

$$
M=\log A+2.31 \log r-1.38, \quad \text { for } r<40 \mathrm{~km}
$$

この式と（1）式を比べると， $M$ の值で最大 0.3 程度のくい違いが生ずることが分る. しか 乙前述のように, jump の大きさは一定しないので $r=30 \sim 40 \mathrm{~km}$ に和いて（2）式から求 める $M$ の精度は必ずしもよくならない。な挆数 $\alpha, \beta$ は一般に一次の関係にあることが知ら れているが [早津 (1955)]，（2）式の係数はこの関係から可成りはずれている.

\section{$\S 3$ 速度振幅から求めたマグニチュード}

微小地震の観測では, 前節でとり扱つた変位計よりも Fig. 1.VS で示す速度型地震計が多 く使用されている．従つて，この速度計（主として上下動成分）での最大動 $\left(A_{v}\right)$ から $M$ を 求める式を導き, 変位の場合と比較した.

Figs. 5 (a) ～(c) は， 微小地震観測網で得られた資料を地震の大きさにより 3 大のグルー プに区別して示した $A_{v} \sim r$ 曲線である. 図中の $\alpha$ はそれぞれのグループについて傾斜を平均 したものであり，r<200 km の範囲では地震の大きによらずほぼ一定である．Fig. 5 の全資 
料から傾斜の平均値を求めると

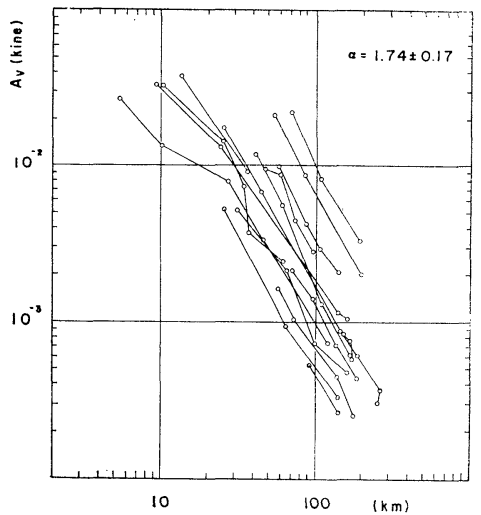

(a)

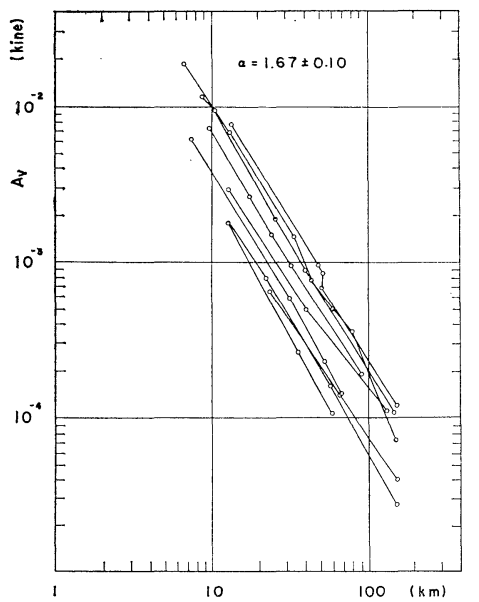

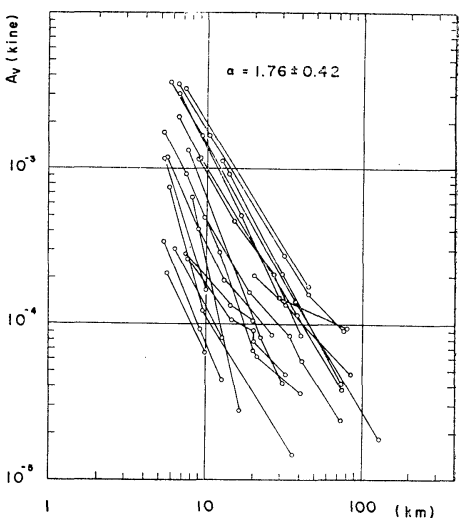

(c)

Fig. 5. The patterns of maximum velocity amplitude $\left(A_{v}\right)$ versus focal distance $(r)$ obtained at the array stations near Abuyama. The value of $\alpha$ in each plot shows the mean value of the decay coefficient for the respective magnitude range. The average value for all of the data is calculated as $1.73 \pm 0.27$.

$$
\bar{\alpha}=1.73 \pm 0.27
$$

となり（1) 式の係数と一致する. また，これらの $A_{v} \sim r$ 曲線には変位についてみられた折 れ曲りや jump は現れず，近距離においても比較的 smooth な直線関係が成り立つている.

次に, $M_{J}$ の值と比べるために $r=100 \mathrm{~km}$ での $A_{v}$ をこの眓から読みとり， $M_{J}$ に対して plot したのが Fig. 6 である。 この関係を直線で表わし $A_{v} を \mu$ kine の単位にとれば, 最 小自乗法で次の式が得られる.

$$
\log A_{v}(100)=0.85 M-5.96
$$

さらに（3）式と組み合わすと,

$$
0.85 M-2.50=\log A_{v}+1.73 \log r, \quad \text { for } r<200 \mathrm{~km}
$$

これは，村松（1964），TERASHIMA（1968）などが定義した速度振幅に関する公式に比べて， 
$1.0 \sim 1.5$ 程度大きい $M$ を与える.

Fig. 7 は $r>200 \mathrm{~km}$ での $A_{v} \sim r$ 曲線である. 曲線の傾きは $r$ と共に急激に増加し，も はや（1）式の形で $A_{v}$ の減衰を表現できない，従つて， $\alpha=1.73$ を固定し，この直線から のはずれを $\gamma=\log \left[\exp \left\{-k\left(r-r_{0}\right)\right\}\right]$ で表わすとすれば, Fig. 8 から

$$
r=0.0015(r-200)
$$

が求められる. 従つて，（5）および（6）式から $r>200 \mathrm{~km}$ での $M$ の定義式が得られる.

$$
0.85 M-2.50=\log A_{v}+1.73 \log r+0.0015(r-200), \quad \text { for } r>200 \mathrm{~km}
$$

後で述べるように，r>200 km では $A_{v}$ を与劣る波の周期がのび，地震計の cut off 周波数 を越えるので，（7）式から $M$ を求める場合.

振幅の補正を正確に行なう必要がある.

Fig. 9 は Figs. 5 (a) ( c) および Fig. 7 の折れ線を滑らかにして重ね合わせたもので ある。また，鎖線は（5）抌よび $(7)$ 式を表 わしている。図にみられるように， $M$ およ びrの可成り広い範囲に実測值が分布してい る.この範囲については, Fig.2およびF ig.3 にみられる程度の精度が期待されるが，（5） および（7）式で外挿した部分,特に $M>6$ の大きい地震についての $M$ の決定精度は今 のところ明らかでない.

\section{$\S 4$ 最大振幅の周期とマグニチュード}

記録上，最大振幅を与光る波が smooth な 表面波ではない場合，その周期の読み取りは 困難なことが多い，乙かし最大值の前後を含 め wave train として平均をとれば誤差を軽 減することができる，このようにして変位計 で読んだ最大振幅に相当する周期 $\left(T_{A}\right)$ を， $M$ について plotしたのが Fig. 10 (a) であ る。黒丸および白丸は $r \fallingdotseq 200 \mathrm{~km}$ を境にし て分けたものであるが，2つのグループ内で

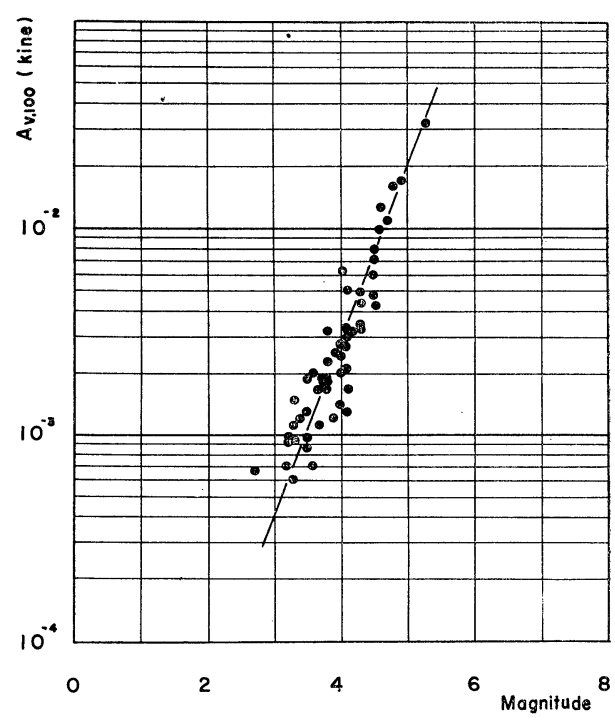

Fig. 6. Maximum velocity amplitudes measured at $r=100 \mathrm{~km}$, plotted against the magnitudes determined by J. M. A.

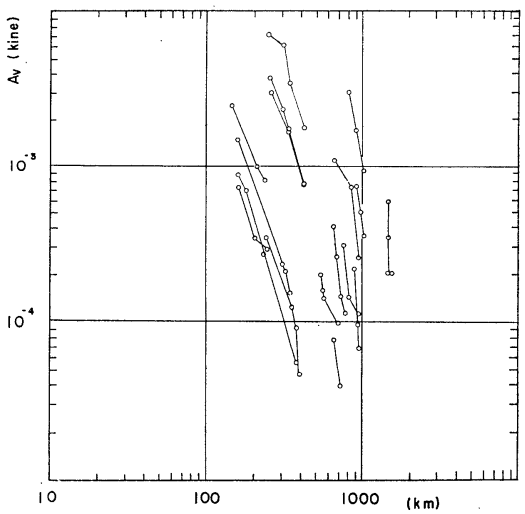

Fig. 7. The same pattern as in Fig. 5 for $r>200 \mathrm{~km}$. 


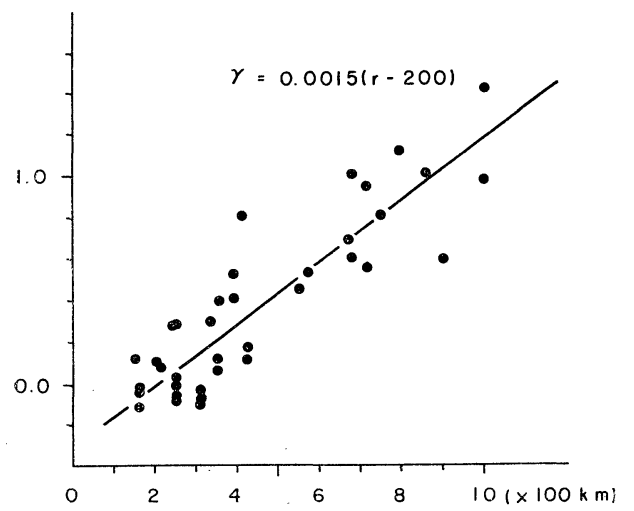

Fig. 8. Deviations from the straight line with gradient 1.73 , plotted against focal distance. The best-fitted correction factor $r$ shows that $A_{v}$ decreases according to a formula, $\exp \{-0.0035(r-200)\} \cdot r^{-1.73}$, within this distance range. $\mathrm{km}$ になると地殼を伝わる表面波が最大振幅を与える（白丸）ことが分る. 図に示してはいな

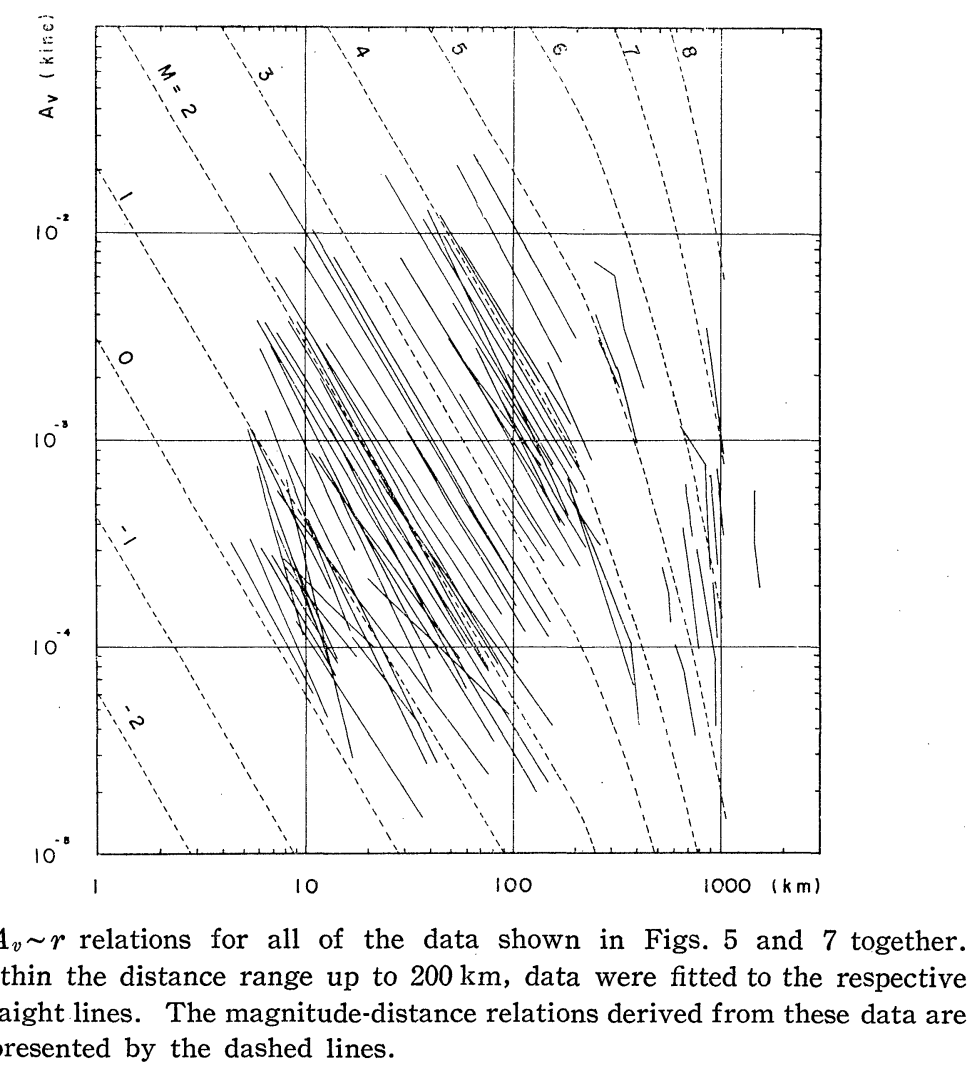

Fig. 9. $A_{v} \sim r$ relations for all of the data shown in Figs. 5 and 7 together. Within the distance range up to $200 \mathrm{~km}$, data were fitted to the respective straight lines. The magnitude-distance relations derived from these data are represented by the dashed lines.
は $T_{A}$ と $M$ はよい直線関係を保ち，それぞ れ次の式で表わされる.

$$
\begin{gathered}
\log T_{A}=0.35 M-1.65, \\
\text { for } r<200 \mathrm{~km}
\end{gathered}
$$

$\log T_{1}=0.32 M-0.88$,

$$
\text { for } r>200 \mathrm{~km}
$$

このような関係についてはすでに多くの報告 があるが [例觉ば KASAHARA (1957)，MATUмото (1960), TERASHIMA (1968)], (8) 式

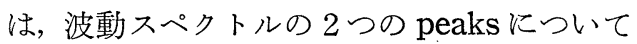
調べた MATUMOTOの結果とよく一致する. すなわち， $r<200 \mathrm{~km}$ では最大振幅は実体 波またはその変成波に相当し(黒丸)，r>200 


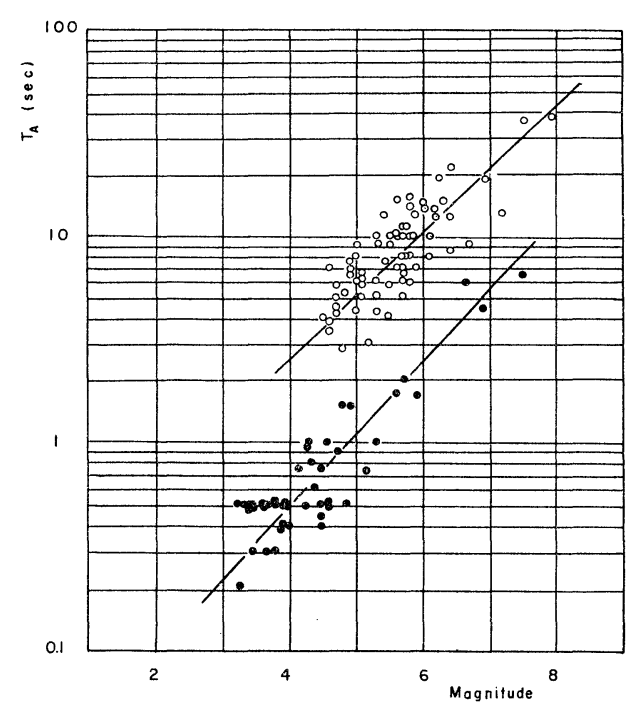

(a)

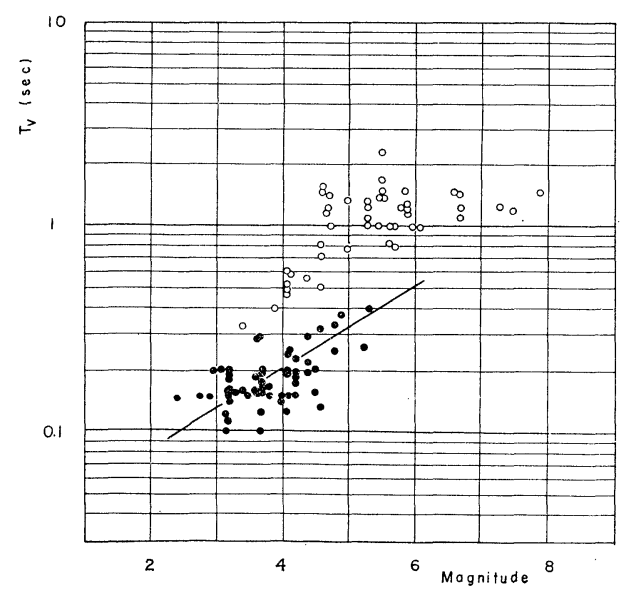

(b)

Fig. 10. (a) Dependence of periods corresponding to the maximum displacement amplitude on earthquake magnitude. Solid and open circles indicate the data of the distance ranges less than and more than $200 \mathrm{~km}$ respectively.

(b) The same plot as in Fig. 10(a) for the maximum velocity amplitude.

いが, $50 \mathrm{~km}$ より深い地震はで $r>200 \mathrm{~km}$ でも黒丸のグループに入り (例宎ば日向灘の地震), 非常に浅い地震 (例觉ば松代地震) で $r<200 \mathrm{~km}$ でも白丸グループに属するものもみられた. これらは地震の深さが最大振幅の出現に大きな影響を及泣すことを示す一例である.

ところで，この図で注目すべき点は，r=200 km で分けられるそれぞれのグループ内では 任意の $\gamma$ にいて（8）式が成り立つことである。すなわち，どちらのグループに属するかは 波の相で自然に決まり， $T_{A}$ は $r$ に無関係で $M$ のみに依存することが明らかになつた．前述 の MATUMOTO の研究では $r$ をぼ一定にとつた場合の議論であり, この点が相違している. また，§2 で述べたように変位計の特性で平坦な部分から得られた資料についてのみこの結果 が成り立つことに注意しなければならない，狭い帯域の地震計では， $T_{A}$ は $M$ に殆んど無関 係で，最大感度を与える周期に近い值になることが確められている [SUYEHIRO (1962)].

Fig. 10 (b) は速度計に関して最大振幅を与える周期 $\left(T_{v}\right)$ と $M$ の関係を示したものであ る.（a）図に比べてばらつきは大きくなつているが，直線で best fit させると次の関係が得 られる。

$$
\log T_{v}=0.20 M-1.50, \quad \text { for } r<200 \mathrm{~km}
$$

一方， $r>200 \mathrm{~km}$ については (白丸), $T_{v}$ が $2 \mathrm{sec}$ たらずで一定になつてしまい全体として 


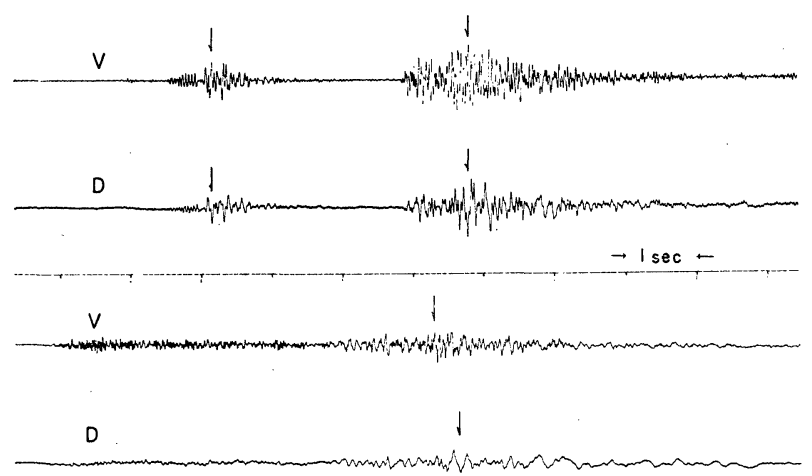

Fig. 11. Pairs of the traces obtained from the velocity seismograph (above) and the traces of displacement component reproduced from the velocity seismograms by means of an electrical integrator (below), showing the fact that the difference in periods corresponding to the maximum amplitudes between the velocity and the displacement seismograms, increases according to the earthquake size.

の直線関係は得られない，これは地震計の速度に対して平坦な部分が， $T_{r}>1 \mathrm{sec} て ゙$ cut off されることによるものであろう。この事実は， $A_{v} \sim r$ 曲線 (Fig. 9) が $r>200 \mathrm{~km}$ で直線か らはずれ急に折れ曲ることによく符号する。

Fig. 11 は，地震計の特性によつて最大振幅の波形がどのように変化するかをみたものであ る. 速度計で記録した原記録（V) とそれを適当な積分回路で変位に変換したもの (D) を並 ベてある． $T_{A}$ と $T_{v}$ の比は $M$ と共に変化し， (8.1) および（9）式の関係を確めること ができる，また最大振幅出現の位置が移り変わる場合もあり，一般に $A$ と $A v$ との関係を $A_{v}=\left(2 \pi / T_{A}\right) \cdot A$ で表わすのは正しくないことを示している. 事実, この関係で $A$ から $A_{v}$ を計算し，（1）（8）式を用いて $A v$ と $M$ の関係を出すと（5）から求めたものに比べて 1.0 以上小さい $M$ を与える.

\section{$\S 5$ 震源スペクトルに関する一考察}

前節では，変位計および速度計で最大振幅を与える周期は等しくなく，浅田 (1953) が定義 した形で卓越周期は決まらないことを述べた。それでは，A と $A v$ は $T_{A} ， T_{v}$ をへてて統計 的にどのような関係をもつているであろうか，先ず，（1），(5) 式からｒ９項を消去し， (8.1)，（9）式を用いると，

$$
A_{v}=C \cdot\left(T_{v} / T_{A}\right) \cdot A, \quad C=3.31 \mathrm{sec}^{-1}
$$

の関係が得られる. 次に速度計で最大振幅 $A v$ を与えた波は変位計では $A^{\prime}$ であるとすれば, $A_{v}=\left(2 \pi / T_{v}\right) \cdot A^{\prime}$ となるので，(10) 式から 


$$
A^{\prime}=(C / 2 \pi) \cdot\left(T_{v}{ }^{2} / T_{A}\right) \cdot A
$$

すなわち， $A^{\prime} / A$ は震源距離に無関係で $M$ のみ の関数で表わされることが分る、こ机は（8）， (9) 式が $r$ に無関係であることから導かれた結果 に他ならない。この推論を押し進めると, 震源で の変位スペクトルの最大值が $A$ に相当し， $A v$ を与える変位 $A^{\prime}$ でスペクトルの他の 1 点を押さ えることができる，この $A$ と $A^{\prime}$ でスペクトル 曲線の一方の傾斜が決まると仮定して,その slope が $M$ または周期でどのように変化するかを示し たのが Fig. 12 である. $A, A^{\prime}$ に相当する 2 点 をもつともらしくつなぎ， $T_{A}$ よりも長周期部分 を平坦にすれば，図中，鎖線で示すスペクトルが 得られる. スペクトルの高さは $M$ と共に 1 桁ず つ変化するが，それと同時に slope の傾きも大き く変つている，従つて，この結果は震源スペクト ルに関する AKI (1967) models とは, 全体とし て一致しない.

以上はあくまでも統計的な結論であつて，1つ 1つの地震波動を解析したのではないことに注意 すべきである。また，前述のように（8)，(9) 式 がとに無関係であること, および最大振幅の減少 の仕方が $M$ および $T_{A}, T_{v}$ によらなと言う重要 な事実を含んでいる。一方，この結果に対して，「震源スペクトルと減衰係数とがお互いにう まく補足し合つて，たまたま $\alpha=$ constant と言う結果をもたらしたに過ぎず，震源スペクトル と波の減衰とは分離して考光るべきである.」と言う反論も成り立つ.これを確めるためには， 従来の研究に加え, 地層構造とそこでの地震波の挙動をさらに精しく調べなければならない。

\section{$\S 6$ ま と め}

阿武山地震観測所の変位計群か求らめられた $M_{0}$ は, $r=1,000 \mathrm{~km}$ までの広い範囲で気象 庁の $M_{J}$ によく一致する. また， $r=200 \mathrm{~km}$ を境にして，最大振幅に相当する相が実体波 
から表面波に変化するにも拘らず，（1）式で定義される $M_{o}$ には大きな誤差は含まれないこ とが分つた．しかし $r<40 \mathrm{~km}$ においては振幅の減り方が大きいので，（2）式を使えば， $M$ の決定精度は多少向上する. ただし， $r=30 \sim 40 \mathrm{~km}$ で $A \sim r$ 曲線に jump が起こり，その 大きさおよび距離は震源の深さに大きく左右されるので, 震源の位置がよく決まらない地震に ついては（1）式を使う方が無難であろう.

次に，微小地震の観測に使われている速度計の資料から（5）および（7）の定義式が得ら れた. Fig. 9 の $A_{v} \sim r$ 曲線にみられるように, $r$ の小さい範囲で折れ曲りやjump は現われ ず，よい直線関係が成り立つている，従つて，近い地震の $M$ は速度計から（5）式を使つて 求めれば，最も誤差が小さくなることが分る，これとは反対に，r>200 km では速度計の cut off 周波数が $M$ の值に大きな影響を及湆すので, 長周期の变位計を用いるべきである。 こ こで注目すべきことは, 変位, 速度を問わず最大振幅の減り方を表わす係数が坪井の值と全く 一致したことである、この事実から， $\alpha$ の值，1.73 は，拡がりつつ減衰する波動を表現する 非常に有意な統計的な常数であることが確められた.

最後に, 最大振幅を与える波の周期から, 震源における变位スペクトルの推定を行なつた. 変位計および速度計で最大振幅を与えるスペクトル成分が相違することを利用して，統計的な 意味で，震源スペクトル上の 2 点を決めることができた。ここに加速度計の資料を加えること ができれば，さらに議論を押し進めることが可能である.

おわわりに当つて，多くの有益を助言をいただいた三木晴男教授をはじめ，阿武山地震観測所 の諸氏に心から抢礼を申し上げる.

文献

AKI, K., 1967, Scaling Law of Seismic Spectrum, J. Geophys. Res., 72, 1217-1231.

浅田 敏, 1953, 地震動の卓越周期と振幅との関係一石本・飯田の式に拈ける係数 $\mathrm{m}$ にいて一, 地 震 II , 6, 69-73.

Evernden, J. F., 1967, Magnitude Determination at Regional and Near-Regionl Distances in the United States, Bull. Seism. Soc. Amer., 57, 591-639.

早津昭男, 1955 , 地震の最大振幅が距離に対して減衰する割合, それと地下構造との関係, 地震 $I$, 8, 75-79.

KASAHARA, K., 1957, The Nature of Seismic Origins as Inferred from Seismological and Geodetic Observation (I), Bull. Earthq. Res. Inst., 35, 473-532.

Matumoto, T., 1960, On the Spectral Structure of Earthquake Waves-the Relation between Magnitude and Predominant Period-, Bull. Earthq. Res. Inst., 38, 13-27.

村松郁栄，1964， Magnitude の定義式について，地震 II, 17, 210-221.

RICHTER, C. F., 1935, An Instrumental Earthquake Magnitude Scale, Bull. Seism. Soc. Amer., 25, 1-32.

SuYEHIRO, S., 1962, Deep Earthquakes in the Fiji Region on the Nature of Deep Earthquakes-, Papers in Meteorology and Geophysics, 13, 216.

Terashima, T., 1968, Magnitude of Microearthquake and the Spectra of Microearthquake Waves, Bull. International Institute of Seismology and Earthquake Engineering, 5, 31-108 坪井忠二, 1954 , 地震動の最大振幅から地震の規模 $M$ を定めることについて, 地震 II, 7, 185-193.

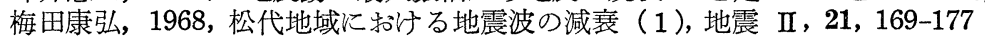

